\title{
Ethnologies
}

\section{DVD Review Essay: Always Been A Rambler. The New Lost City Ramblers. Dir. Yasha Aginsky. Arhoolie Foundation, DVD 204, 2009. (Available: www.arhoolie.com)}

\section{Graham A. Blair}

Volume 32, numéro 1, 2010

Jouer

Play

URI : https://id.erudit.org/iderudit/045228ar

DOI : https://doi.org/10.7202/045228ar

Aller au sommaire du numéro

\section{Éditeur(s)}

Association Canadienne d'Ethnologie et de Folklore

ISSN

1481-5974 (imprimé)

1708-0401 (numérique)

Découvrir la revue

Citer ce compte rendu

Blair, G. A. (2010). Compte rendu de [DVD Review Essay: Always Been A Rambler. The New Lost City Ramblers. Dir. Yasha Aginsky. Arhoolie Foundation, DVD 204, 2009. (Available: www.arhoolie.com)]. Ethnologies, 32(1), 245-262.

https://doi.org/10.7202/045228ar d'utilisation que vous pouvez consulter en ligne.

https://apropos.erudit.org/fr/usagers/politique-dutilisation/ 
qui constitue un apport théorique valable aux débats que connaissent nos sociétés sur la place de la diversité dans nos milieux scolaires.

Stéphanie Arsenault

Université Laval

\section{Références}

Waldmann, Peter, 1989. «Ethnischer Konflikt und Klassenkonflikt : ein Diskussionsbeitrag zu widersprüchlichen Theoriansätzen». In Peter Waldmann et Georg Elwert (eds.), Ethnizitat im Wandel. Saarbrücken. Breitenbach.

\section{DVD Review Essay}

Always Been A Rambler. The New Lost Clty Ramblers. Dir. Yasha Aginsky. Arhoolie Foundation, DVD 204, 2009. (Available: www. arhoolie.com)

Popular treatments of that period of the late 1950s and early 1960s referred to as "the American Folk Revival" tend to focus on the protest singing of figures like Joan Baez and how, in the case of Bob Dylan, this transformed into a style of original songwriting inspired as much by the poetic ramblings of beat generation poet Allen Ginsberg as the topical songs of Pete Seeger and Woody Guthrie. Indeed, Dylan became so strongly associated with the folk revival of this period that his electric performance with the Paul Butterfield Blues Band at the 1965 Newport Folk Festival is often considered to be one of its bookends, the other being when the Kingston Trio's collegiate-lite version of the folk ballad "Tom Dooley" topped the popular music charts in 1958, bringing the revival to mainstream audiences. Far from representing a distinct beginning and end, however, the "folk boom" of 1958-1965 (see Rosenberg) was part of a much longer process of folk revivalism within American history that can alternately be demarcated by major political and social events, in this case the witch hunts of the McCarthy era and the senseless violence of the Vietnam war.

The transformation of protest songs into folk rock is also only part of the story. A history less often told is how this period of intense interest in "folk" music led a subset of urban revivalists to seek a sense of history and rootedness by turning to older stringband traditions as an alternative not only to what they perceived as the postwar void of American culture, 
but also as an alternative to the popularized and politicized forms of folk music current at the time. It is worthy of note that this development became significant in Canada as well. In Vancouver during the 1970s, for example, a group of counterculturally-inclined youth who were turned off by the purism they saw at work in the Vancouver Folk Song Society decided to establish their own club, the Pacific Bluegrass and Heritage Society, which has been the centre of a thriving bluegrass and oldtime music scene in that city for over thirty years. In addition to nurturing local bands like Highrise Lonesome, Redgrass, and Viper Central, members of this and similar clubs have contributed to the development of regional festivals and workshops which are now part of a network that spans the entire country. At the vanguard of this North American "traditional music movement" was a Greenwich Village-based trio called the New Lost City Ramblers, originally consisting of Mike Seeger, John Cohen, and Tom Paley, with Paley later replaced by Tracy Schwartz. The Ramblers took as their musical point of reference not the political folk songs of blacklisted activist Pete Seeger and his comrades but commercial "hillbilly" recordings from the 1920s and 1930s which channelled, to paraphrase Greil Marcus, an older and weirder world of American music that defied simplistic notions of folk music (Marcus 1997). As gathered on Harry Smith's three-volume Anthology of American Folk Music, released in 1952 by what was then a local New York record label called Folkways, these old 78s became the basis not just of a new emphasis on sound and style, but would be a catalyst in the grassroots revitalization of stringband traditions across North America .

Yasha Aginsky's DVD documentary Always Been a Rambler (2009) speaks to this history on a number of levels, animating a story that has largely been told only piecemeal in studies of this period and scattered across the liner notes to the many records the New Lost City Ramblers made for the Folkways label in the late 1950s and through the 1960s. As is discussed below, some of the more interesting facets of this story are found in the notes that founding members Mike Seeger and John Cohen wrote to accompany not just their own recordings, but those they made of older southern musicians they sought out at country music parks, fiddling conventions, and small Appalachian towns. Both in their original form and as revisited in the 1990s for the Smithsonian CD reissues of the Folkways catalogue, the personal statements and recollections contained in these liner notes often provide great insight 
into what motivated the members of the Ramblers to dedicate themselves to "old-time music" (originally a marketing designation of commercial recordings first used by OKeh Records in 1924), and on what terms they engaged older musicians. These notes will be explored in some detail here as a means of filling out the history introduced in Always Been A Rambler, a documentary which is commendable in taking seriously the activities of urban revivalists and their enduring legacies, but often skips the surface of this history, failing to consider, for example, the broader ideologies which were and are still at play among practitioners of oldtime music, particularly on a grassroots level.

Indeed, by focussing primarily on the influence that the New Lost City Ramblers had on people who are now professional musicians from David Grisman and Maria Muldaur to Abigail Washburn and a contemporary African-American stringband called the Carolina Chocolate Drops - Always Been A Rambler misses important dimensions of the Ramblers' legacy that continue to be articulated on both local and international levels. Together with fellow Greenwich Village scenemaker and future folklorist Ralph Rinzler, Mike Seeger and John Cohen produced dozens of recordings by oldtime musicians that circulate today under the stewardship of the Smithsonian Institution, making the sounds of Wade Ward, Roscoe Holcomb, Dock Boggs, and Clarence Ashley, to name only a few, widely known to subsequent generations. Through an organization called the Friends of Oldtime Music, these three introduced older southern musicians to new, and markedly younger, urban audiences, providing performance venues for them via a network of coffeehouses and college folk festivals throughout the continent. Not only would the New Lost City Ramblers contribute to the development of the many urban stringband music scenes across the North America in their travels - process that was noted as early as 1967 in a review article by folklorist Ed Kahn when the mainstream folk revival was on its deathbed — but their influence would be felt even further afield; in discussing the spread of the American folk revival within postwar Japan, for example, Toru Mitsui remarks that the recordings of the New Lost City Ramblers were instrumental in drawing a new audience to early stringband music in that country.

The legacy of the New Lost City Ramblers has been multifaceted, providing the model for local citybilly stringbands across North America and playing a foundational role in the interchange between rural and city folk that continues to inform oldtime musical practices today on a 
grassroots level. For me, an Ontarian who relocated to British Columbia, it is also close to home; my own research on bluegrass and oldtime music scenes in Western Canada frequently reveals the influence of the New Lost City Ramblers in the personal histories of participants, and they are entangled in my own story in several ways. I was first exposed to older stringband traditions through the music of the Grateful Dead, in particular the acoustic side-projects of lead guitarist Jerry Garcia who, it turns out, was deeply influenced by the New Lost City Ramblers as a young San Francisco-based "folknik" in the early 1960s. I would also discover that the member of the local Vancouver bluegrass club who largely inspired me to learn oldtime clawhammer-style banjo was himself led in this direction by the New Lost City Ramblers, though a generation before. In a more direct manner, it was after seeing Mike Seeger perform with his wife at the Vancouver International Folk Festival in 2005 that I decided to pursue oldtime music more seriously, beginning with the purchase of one of Seeger's instructional DVDs, Old-Time Banjo Styles, released through Homespun Video (1992). Since that time I have participated in many grassroots picking scenes, both in Canada and the United States, whose lineages can be traced back, in some form, to the activities of the New Lost City Ramblers during the height of the American Folk Revival.

\section{A Celebratory History}

Mike Seeger (b. 1933) passed away after a struggle with cancer in the summer of 2009, the same week that a copy of Always Been A Rambler arrived in my mailbox. Far from being a scholarly documentary, this relatively short film presents a celebratory history of the New Lost City Ramblers that touches on much of the history summarized above, though it really only tells part of the story, ultimately falling back onto familiar categories rather than taking the opportunity to truly revise popular understandings of the revival. In setting the tone, the documentary begins with black and white footage of the Ramblers playing on what is presumably a film set made to look like the interior of an old clapboard house, an oval portrait of a stone-faced man hanging on one wall, and two American flags crossed on another, high above where Mike Seeger sits at a kitchen table playing second fiddle to Tracy Schwarz. This is the New Lost City Ramblers as they existed after Tom Paley left the band in the early 1960s — partly for political reasons, as he suggests later on in the documentary, but largely because he didn't 
want to make music a full-time profession at that time, and this was the direction that Mike Seeger and John Cohen wanted to go. Having established an historical image of the Ramblers, the film switches from this relatively controlled tableau to cinéma vérité-style footage of Cohen, Seeger, and Schwarz in the present, fussing over a tie backstage before a performance at the 2007 Hardly Strictly Bluegrass Festival, a free multi-day concert held each year in San Francisco's Golden Gate Park where much of the contemporary footage included here was filmed. Obviously much older, the Ramblers are nevertheless playful and spirited, possessing an ease and humour you might expect of grandfathers at a family reunion, the image of them cultivated by Always Been A Rambler.

Introducing the New Lost City Ramblers through this contrast, the film then takes the viewer into the past again, though this time the black and white footage is of Bill Haley and the Comets performing "Hot Dog Buddy Buddy" on a television special in 1956, surrounded by teenage dancers as they rock out their Western Swing version of "jump" style rhythm and blues. A voice-over explains: "Back in the 1950s, many young musicians were looking for alternatives to commercial American culture and popular music of the day. Some chose rock and roll, some chose blues, others chose modern jazz. The New Lost City Ramblers fell in love with oldtime rural American music." As the documentary shifts to 1966 footage of the Ramblers playing in front of an old mill, the narrator adds: "For inspiration they went straight to the source, seeking out authentic [my emphasis] musicians, and keeping the old sounds alive by passing them on to new audiences." This notion of authenticity is picked up a bit later on during a segment showing a montage of old stringband groups from around the turn of the century, the voice this time describing oldtime music as follows: "The oldtime music of the New Lost City Ramblers has deep roots. It's an expression of the way Americans lived when most of them still lived on the farm. Their songs blend European and African influences with popular tunes of the early twentieth century. The result is as uniquely American as jazz or blues. It began with just fiddle and voice. The banjo came from Africa on slave ships. Later, guitar, mandolin, and other instruments were added to the mix." As a popular account, this brief historical sketch is fair enough, but the narrator continues to claim, despite these diverse influences: "Oldtime music had been handed down from generation to generation before being recorded for the first 
time in 1922." The film then shifts to Pete Seeger describing oldtime recordings of the 1920s as capturing "some of the best folk music in America."

From a representational standpoint, I find this bald reiteration of familiar categories troubling because it plays into stereotyped notions of traditional music and authenticity that neither Pete Seeger or the New Lost City Ramblers shared. Pete Seeger, for example, used the term "folk music" frequently but broadly because for him it was not simply a collection of songs "handed down" unchanged like a football in some kind of intergenerational rugby match. In a contemporary article titled "Why Folk Music?," originally published in a 1965, Pete Seeger would directly challenge static definitions of folk music that freeze it in set repertoires, forwarding instead a processual definition of traditions that was quite nuanced for its time: "There are many definitions of folk music, but the one which makes most sense to me is the one that says it is not simply a group of old songs. Rather, it is a process, which has been going on for thousands of years, in which ordinary people continually re-create the old music, changing it a little here and there as their lives change." Most interesting is Seeger's answer to the question of why city-bred youths are drawn to folk music, which he addresses by way of explaining why he first began to play folk music at the age of sixteen in 1935. Falling in love with the five-string banjo at a square-dance festival in Asheville, North Carolina, Seeger relates that he came to reject both the popular jazz he had previously played along with the classical music of his parents, who were then teaching at Julliard. He goes on to describe why folk music had such an impact:

Compared to the trivialities of most popular songs, the words of these songs had all the meat of human life in them. They sang of heroes, outlaws, murders, fools. They weren't afraid of being tragic instead of just sentimental. They weren't afraid of being scandalous instead of giggly or cute. Above all, they seemed frank, straightforward, honest. By comparison, it seemed to me that too many art songs were concerned with being elegant and too many pop songs were concerned with being clever.

It is the fundamental humanity that he perceived in pre-commercial forms of music that was of importance, a complex musical response that was specific to his particular cultural experience and is not reducible to the simplistic terms of debates about authenticity. 
The reasons why the New Lost City Ramblers were drawn specifically to oldtime music were similarly nuanced, and have been expressed most vividly in the liner notes to their numerous Folkways releases. Importantly, these notes repeatedly emphasized the diversity of music heard on early hillbilly recordings not just in countering homogenized ideas of folk music, but also in stressing that hillbilly music, though rooted in older fiddle traditions, was a creative response to transition, expressing in its nostalgia the longings of uprooted country folk-a sense of uprootedness with which these citybillies could relate. In the notes accompanying their self-titled debut, for example, Tom Paley would describe what the New Lost City Ramblers played as "music of the borderline," and one gets the impression that it is because of this complex parentage that they, as discontented youth living in America's largest and most diverse urban centre, felt justified in their identification with this music. Drawing attention to the increased interaction between city and country people throughout the early twentieth century, Mike Seeger would similarly emphasize in his contribution to these notes the changes that were occurring musically during this period, as new instruments were introduced to the mountains along with new types of songs. "This was a period of great experimentation," Seeger points out, "when country people were learning new instrumental and vocal techniques, affected sometimes by urban or Negro music, and where there was small similarity between any two performers or groups." Old repertoire was adapted, new styles were incorporated, and when the early recording companies discovered the commercial possibilities of country music in the 1920s, they set up field studios in furniture stores and trailers where they recorded the great variety of music being produced by this generation of mountain musicians. "Away from music," Seeger adds, drawing attention to class interactions within this musical culture, "these men were a good cross section of the population with occupations ranging from miner and moonshiner to farmer and doctor."

Against this understanding of the music, the New Lost City Ramblers positioned themselves as revitalizing, and not simply reviving, older traditions of stringband music. The idea that they had formed a bridge between these older southern stringband traditions and newer ones then developing in northern cities would be revisited often in later notes, notes which would remark upon the increasing number of stringbands that emerged in the early 1960s as the Ramblers travelled across the country performing at various college campuses and festivals. 
As early as 1959, in the notes to The New Lost City Ramblers, Vol. II, John Cohen commented in this connection: "In the last two years we have been singing in concerts and at colleges and clubs all over, and seem to be finding friends where we never knew we had them. In many colleges small country string bands have been springing up and have taken a real place in the general field of folk music. In the city and at the colleges they have broadened the definition of traditional music to include the living and growing aspects of the music." By 1964, in the notes to Rural Delivery No.1, John Cohen would articulate the ideology underlying what had by that time grown into a fully-fledged movement, an ideology which continues to be expressed by participants in oldtime and bluegrass music scenes today: "For us, it has become a personal and handmade statement in the midst of mass produced mass culture. It is a way of dealing with the past and present, a connection with people faced with similar problems - a simple statement of basic human needs, or a highly sophisticated and stylized expression of an old tradition which is still at work." In other words, it was political, but without being overtly so.

\section{Beat Folk}

Lacking an exploration of such meanings, Always Been A Rambler fails to properly situate the New Lost City Ramblers within the historical setting that nourished them - namely, a postwar Greenwich Village where young Americans were looking back not only to folk music, but also to the earlier bohemian art movements that once flourished in this part of New York City. In his 1956 poem America, poet Allen Ginsberg famously asked when his country would end the human war, turning his back on its unbridled selfishness with words that might be spoken by a betrayed lover: "Go fuck yourself with your atom bomb. I don't feel good don't bother me." Although it is often remarked that the folk crowd was despised by the beats, who found the soundtrack to their cultivated madness in modern jazz, both nevertheless shared overlapping milieus. Not only was Greenwich Village one of the major centres where both of these scenes found expression, but it was also home to likeminded people participating in a range of creative practices, as is made clear in John Cohen's retrospective book of photography, There Is No 
Eye (2001). Here Cohen writes of returning from a trip to Peru in 1957, not long before the New Lost City Ramblers were formed, and settling in a cheap New York City loft amidst the "creative ferment" of a community of artists and co-operative galleries. It was the height of Abstract Expressionism, a period which also saw the beginnings of the Pop Art movement and the "happenings" which would flourish in Soho during the 1960s, but were then self-consciously avant-garde affairs, involving mock battles between emerging artists like Claes Oldenburg and Jim Dine, wielding wooden swords and wearing lampshades and tablecloths in front of audiences of other artists, poets, and writers. "It was a meeting ground for a smaller art world," Cohen remarks, "where artists had shows with few prospects of sales or reviews." The lofts were illegal, located in what Cohen describes as "the grimy no-man's land" between Greenwich Village and the Lower East Side, with drunks from the Bowery sprawled out on the sidewalks. Cohen's loft was where he painted, printed photographs, and slept, and it was also the space where the New Lost City Ramblers would practice. "From my Third Avenue base I went out on concert tours with the NLCR and on photography expeditions to the rural South," Cohen recalls. "I shot my first test roll of movie film at the loft, a silent three-minute view of young Bob Dylan on my roof. In the loft I also photographed Dylan, Alan Lomax, and the Kentucky singer Roscoe Holcomb. The Stanley Brothers and Woody Guthrie visited, along with a stream of other musicians and artists." Cohen adds, aware of the deceptions of memory: "Over the distance of time, those years on Third Avenue seem very exciting, but in reality it felt mostly desolate and run down."

The photographer Robert Frank, who took the band photo used as the cover of Always Been A Rambler, lived in an adjoining loft with his family, and Cohen recalls in particular the impact that Frank's work had on him. Viewing an assortment of images sprawled out on the floor of Frank's loft in 1957 while he was assembling The Americans, Cohen relates that he perceived in those photographs "an emptiness in America" and "the feeling of a hollowness and corrosion that was coming over American life." A year after the New Lost City Ramblers were formed, Cohen went on a trip to Kentucky in the spring of 1959, during which he would make his first recordings of Roscoe Holcomb along with a number of other oldtime musicians. Cohen speaks of the prevailing sense of poverty he experienced down south, and the threat of violence underlying relations between coal miners, their unions, and 
the mine operators: "It seemed as if the rural people of Appalachia were stranded in an increasingly mechanized America," he comments. "These were the descendents of the pioneers, still holding on to old American rural traditions, and suffering because of it. They were stuck in poverty while the rest of America was prospering. How different their lives were from what was on TV."

Importantly, Cohen speaks in There Is No Eye of the role that music played in bridging the cultural divide between himself, the grandson of Jewish immigrants from Russia on both sides, and these economically depressed rural southerners who, from his perspective, were a direct link to an older America that had been abandoned in the name of progress and the postwar dream of a suburban middle-class utopia embraced by his own parents. "As a child I had heard my parents sing sentimental songs and folk songs," Cohen says. "Out in the world, I eventually heard the tougher, hard biting music of traditional singers who made my childhood seem like a sheltered illusion. Yet throughout it all, the music conveyed the message that there was another kind of a life out there." Defending the backward-focus of the New Lost City Ramblers in the notes to a 1961 release, John Cohen would reveal how such interactions with southern musicians were at the time transforming his understanding of the music they played, leading him to take a more complex view of "folk" and "traditional" music: "More and more we find certain attitudes in today's country musicians which will be considered 'folk' twenty years hence," he wrote, "just as some of the commercial singers of thirty years ago are considered 'traditional' today." He suggests that these kinds of labels are inappropriate because they do not reflect the way the musicians themselves think about their music, despite the fact that they may have strong feelings about continuing to do things in the "old time" way. Early stringbands of the 1920s, such as Charlie Poole and the North Carolina Ramblers, drew upon ragtime, swing, jazz, and the blues in crafting their sound as much as they did "traditional" material. "To them," Cohen comments, "it was, and is, alive." He adds, driving home the point: "Coming from the scholars and academicians, the terms 'folk music' and 'traditional' have also meant a death certificate-as if such titles were a guarantee that the music was finished and belonged only to history."

\section{Friends of Old Time Music}


Lacking a critical engagement of concepts like "authenticity," "folk," and "traditional music," Always Been A Rambler presents a history that is accurate with respect to basic outlines, but fails to convey the complex social processes at work, both on an ideological level, as discussed above, and with respect to the relationships John Cohen and Mike Seeger came to establish with the older southern musicians they emulated. In this respect, there are many missed opportunities. As the documentary relates through the recollections of founding members, for example, the Ramblers first started playing together informally in the context of the hootenanny-style folk music gatherings that grew in popularity among college students through the 1950s; enthusiastic about their musical collaborations, John Cohen approached Moses Asch of Folkways Records about the possibility of recording an LP. As Cohen phrased it, there was "no audition, no investigation, no doubts, no questions," and in an inverse fashion the Ramblers recorded their first LP before really performing together in any kind of public capacity. As the first pressing of five-hundred records got around, invitations to perform started coming in, landing the Ramblers a spot at the first Newport Folk Festival in 1959. The attention drawn to their performance in media coverage of the festival led to a snowballing of interest in oldtime music, and the Ramblers would go on to record an astonishing dozen-and-a-half LPs for Folkways at the height of the revival between 1958 and 1965. Despite the prominent role that Moses Asch played not only in unquestioningly supporting the Ramblers as a band, but in supporting the various recording projects of its individual members with southern musicians over the years, he remains only a name in Always Been A Rambler, and there is no consideration of the role that Folkways Records played in the revival at all.

Regarding how their own interest in the music developed, there are similar missed opportunities. Mike Seeger talks about how he grew up singing at home with his mother and father - composer Ruth Crawford and musicologist Charles Seeger — noting that his parent's own desire to keep oldtime music alive shaped the direction of his own life. Although Mike Seeger is shown picking aluminum discs from the family's old phonograph collection, these copies of field recordings made by figures like Alan Lomax and Sydney Cowell are left unexplained. We never learn, for example, that Charles Seeger was involved in the Resettlement Adminstration at the height of the Depression in the mid1930s as director of the music program operated through the Tehnical 
Skills Division, a role that would bring him into close contact with many porminent folklorists, including John and Alan Lomax, Herbert Halpert, and Ben Botkin, eventually leading to a position as deputy director of the Federal Music Project. Anticipating the pathway taken by his own sons, Charles Seeger had a change in musical focus after he heard a Kentucky-born ballad singer and union organizer named Aunt Molly Jackson sing protest songs using folk idioms at a New York rally in 1931; realizing the irrelevance of the avante-garde compositions he and fellow composer Henry Cowell were making on behalf of "the masses" as part of the Marxist-leaning Composers Collective, Seeger would instead dedicate his life to music that was relevant to working class people. Importantly, Charles Seeger's years working for president Roosevelt's New Deal agencies resulted in the contribution of about a thousand recordings to the Library of Congress's Archive of American Folk Song, many of which ended up in a wooden box in the Seeger household, the very one that his son Mike Seeger is shown looking through.

Not all opportunities are missed, however. The complexity of Mike Seeger's personal history comes across most pointedly in Always Been a Rambler when he speaks about getting his first tape recorder in the early 1950s. Although he would seek out country and bluegrass musicians sometimes in distant places over the next decades, his first recordings were made in his own home, featuring the Seeger family's AfricanAmerican maid, a woman named Elizabeth Cotten who specialized in a distinctive style of finger-picked guitar. As Seeger also relates in the notes to a collection of his field recordings of oldtime music from 1952 1967, appropriately titled Close To Home, Cotten had been working at the house for several years before his sister Peggy discovered that she could play both guitar and banjo, though at the time Cotten owned neither of these instruments. In November of 1952, Mike and his brother Pete recorded her playing fifteen pieces, including an original song called "Freight Train," which has since become a standard in both oldtime and bluegrass circles. A highlight of Always Been A Rambler is hearing Cotten describe how the Seeger children would wash the dishes for her while she played guitar for them in the kitchen, and despite their obvious social distance, Mike Seeger speaks of her in the most respectful terms. Notably, the idea behind the Friends of Old Time Music came out of a concert organized by the New Lost City Ramblers in December of 1960 at Israel Young's Folklore Centre in New York; knowing they could 
draw a sizeable audience who wanted to hear their music, the Ramblers used this as an opportunity to feature Elizabeth Cotten, and over subsequent years they would do this with a number of other musicians, including Roscoe Holcomb, Clarence Ashley, and Dock Boggs.

Because Always Been A Rambler does not flesh out these sorts of relationships, it often creates the impression that the influence was a one-way street, with the Ramblers and their contemporaries acting merely as conduits for the transmission of living traditions to a wider audience. This is particularly pronounced in a scene which shows them speaking with Doc Watson at the Hardly Strictly Bluegrass Festival in 2007. While Watson is presented here with all the gravitas surrounding a "traditional" musician, being one of the southerners brought into the revival through the New York folk scene, he is only ten years older than Mike Seeger and his story is considerably more complex than what is suggested here. As recounted in the notes to The Original Folkways Recordings of Doc Watson and Clarence Ashley, Seeger's longtime collaborator Ralph Rinzler had a chance-meeting with a musician named Clarence Ashley at the Union Grove Fiddler's Convention in 1960, where Rinzler was competing with his Greenwich Village-based bluegrass band the Greenbriar Boys, a notable fact in itself. Like many of his contemporaries in the folk scene, Rinzler knew Ashley through two outstanding recordings from the 1920s included on Folkway's Anthology of American Folk Music (1952) — "The House Carpenter" and "The Cuckoo Bird" — and it was a revelation for him to find this legendary oldtime performer alive and well.

As Rinzler further relates in these liner notes, however, at that time Ashley hadn't played music on any regular basis for two decades, and Rinzler asked him if he would be willing to borrow a banjo and work up some material for a recording. When Rinzler visited several months later, he found that Ashley had decided not to pick up the banjo again, but wanted to sing to accompaniment provided by a blind guitarist named Doc Watson. Although Watson is now famous for his acoustic flat-picking, at that time he was playing electric guitar in a rockabilly band, and as Rinzler would later recall, Watson was resistant to the idea of playing acoustic accompaniment: "Doc had made it clear that he had his own professional standards. He owned no acoustic guitar, and if he were to borrow one, he wouldn't be accustomed to it." After much negotiation, Ashley and Watson came around, and under Rinzler's guidance they would go on to make a number of recordings for Folkways 
records, appearing before young urban crowds in a series of dates early in 1962, beginning with a concert organized by the Friends of Old Time Music. Working with Rinzler in further shaping his repertoire, Doc Watson's solo career was launched under fortuitous circumstances during an engagement at a coffeehouse in Los Angeles called the Ash Grove when Ashley was too sick to perform.

Commenting on the more general impact of such activities among his peers, John Cohen would remark: "We set a model of activity which encouraged many other young people to do similar work in the field: collecting, recording, meeting and getting to know traditional musicians as people and as friends, as well as learning to play their music as a form of personal enrichment." Importantly, interactions between citybillies and rural folk became increasingly common in their wake. Folklorist Richard Blaustein (1993), for example, describes how he moved from the folk revival based in New York City into old-time fiddling via the New Lost City Ramblers. Following their model, Blaustein sought out country fiddlers in western New England who, he found, were more than happy to teach this young Jewish kid from New York City. In 1966, he became a member of the Vermont-based Northeast Fiddlers Association, describing this as bridging "the gap between something that was being called a revival (but which was really more like a crosscultural transfusion) and a genuine grass-roots folk revival of fiddle music that was spreading across the United States and Canada without any apparent attention from professional folklorists." Despite the obsession with authenticity expressed by those who Blaustein characterizes as the "kingpins of the urban folk music revival," it mattered little to these older musicians that he was not from a fiddling background, born and bred in New England. Rather, Blaustein found that once he established credibility as a competent fiddler, he was fully incorporated into the world of contest fiddling, even acting as a certified judge at competitions.

This kind of openness was also evident in the relationships that John Cohen and Mike Seeger would forge with the southern musicians they came to know, and it is a shame that this history is not developed in Always Been A Rambler because it reveals the truly unique vantage point they developed. In the notes to their fourth self-titled LP, John Cohen would talk about how the New Lost City Ramblers felt like they were "scraping the bottom" of the folksong barrel when they first began because their exposure was primarily through old 78 records of the 
type heard on Harry Smith's Anthology and through the many record collectors they personally knew. "It was with a sense of finality that we approached our material," he says, "and we had little sense of which paths were yet to be explored." This changed when they began to engage living musicians like Roscoe Holcomb and, in Mike Seeger's case, Dock Boggs, bringing them to revival audiences under the auspices of the organization they founded with Ralph Rinzler called the Friends of Old Time Music. Importantly, they saw this as a form of reciprocity, in some cases keenly aware that the enthusiastic response such musicians received in distant places like New York City were often markedly different from how their music was viewed at home. As a way of illustrating the cultural divide that separated them, John Cohen once noted that Roscoe Holcomb was often unable to play because his hands were so badly cracked from working construction jobs. Despite their economic and social distance, however, Holcomb's music was not appreciated by his own family, and in Cohen he found both an ally and a friend. "He was tolerated," Cohen would recall in this connection, "but there was little feeling for his music, which was met with indifference or scorn." In the notes to the Folkways release Dock Boggs, Legendary Singer and Banjo Player (1964), Mike Seeger would similarly relate that Dock Boggs, largely because of his religiously conservative wife, had pawned his banjo to a friend in the early 1930s and hadn't played for twenty-five years by the time Seeger sought him out in 1963. "He is pleased to be able to pass on to the younger generation his own style of music," Seeger related in the notes to the first set of Folkways recordings he made of Boggs, "which he feels is so much a part of him." In this case, the younger generation were not members of his own family, but the urban folk crowd.

\section{Remembering the Ramblers}

In an interview with John Cohen published in the notes to the Folkways release The High Lonesome Sound (1965), Roscoe Holcomb would summarize his views of music most eloquently: "You know music, it's spiritual. You can take just a small kid, I've noticed, that can't even sit alone, and you pull the strings on some kind of instrument - fiddle or banjo, you watch how quick it draw the attention of that kid. And he'll do his best to get a hold of that. It draws the attention of the whole human race." Writing of the influence that musicians like Holcomb and Boggs had on his contemporaries, Mike Seeger would comment in 
the Verve-Folkways LP notes to Rural Delivery No.1 (1964): "[M]any of us, somewhat like the children of the traditional singers we admire, have not been able to clarify our place within the urban folk song world. We have tended to divert attention from ourselves and the music and direct it instead to a cause-in our case, to the cause of traditional folk music." I'm not sure if Mike Seeger or the other members of The New Lost City Ramblers ever really did find their place within the folk revival, and one must still ask if they really were the children of these older performers. However, the dialogue that Always Been A Rambler encourages by seriously considering the lesser-known legacies of this period is certainly needed, and the alternative vision this film provides could be a valuable contribution to a teaching syllabus that critically engages representations of the American Folk Revival of the 1950s and 1960s. This past decade in particular has seen the release of a number of related documentaries, notably Martin Scorsese's epic treatment of Bob Dylan in No Direction Home (2005) and Jim Brown's biography of Pete Seeger in The Power of Song (2007), both of which I have used as teaching aids in classrooms. Though less grand in scale, Always Been A Rambler nevertheless tells an important story only briefly mentioned in these other films - that of the traditional music movement - and at just under an hour it can easily be shown in its entirety.

Having the ability to see and hear this past through film has become particularly significant as key figures like Mike Seeger pass on. Despite the shortfalls of this film, Yasha Aginsky must be commended for bringing elements of this story to life, and on such respectful terms; the images of Mike Seeger presented in Always Been A Rambler reveal a man who was not just musically talented, but deeply generous and kind. On the other side, Robert Cantwell has written unsympathetically about the image cultivated by Mike Seeger in his later years, emphasizing not these aspects of his personality, but focussing instead on his background of privilege: "What complicates the picture is that while he rescues in folk music the values dear to his class, values that typically include contempt for modern commonplaces such as mass production and mass culture, Seeger is also, through that music, in lifelong revolt against his class - and hence permanently exiled to that strange zone where the very phenomenon of social differentiation seems to have exhausted itself." Cantwell dismisses Seeger as profoundly romantic, comparing him to a blackface minstrel who can come into possession of himself 
only by way of disguise, recovering the essence of his nobility - the choosing of virtue over power - by way of an act of condescension.

Cantwell knows this well, by his own admission, because he recognizes it in himself as someone who participated in the folk revival. But his characterization of this subset of revivalists as "the new minstrelsy" is perhaps more suggestive than he realizes. W. T. Lhamon's study of minstrel pioneer Thomas Rice, Jump Jim Crow (2003), reveals that his version of the Jim Crow character was a vehicle through which the socially mobile of early nineteenth century America subverted the elite values of the establishment. Blackface Jim Crow, as conceived by Rice, was an amalgam - a Lenny Bruce and a Richard Pryor - whose hybridity interrogated the racial as well as class assumptions of those who held power. While I don't think Mike Seeger was a wheeling stranger, I don't know if it is fair to characterize him as a patriarch. Perhaps Bob Dylan's description of a young Mike Seeger as "the knight errant," being "the romantic, egalitarian and revolutionary type all at once," is the best way to remember him. The New Lost City Ramblers were shape shifters and, in their own time, they were tricksters of a sort. They perceived a diversity among "traditional" mountain musicians in those old $78 \mathrm{rpm}$ records that implicitly challenged the romanticized notions of Appalachian music circulating within the folk movement, and perhaps among themselves. Seeking out figures like Dock Boggs, who had become legendary through the alchemy of Harry Smith's Anthology, as well as extraordinary musicians like Roscoe Holcomb, who was never recorded but could well have been, Seeger and Cohen came to understand the histories of these people intimately, and first-hand. That they presented these ageing musicians to young college audiences, and sometimes alongside their own minstrel performances, can be interpreted as an implicit challenge to the facade and inventions of the folk revival. These were the enfranchised values that the New Lost City Ramblers probed through their ambiguous art.

Graham A. Blair Memorial University St.John's, Newfoundland and Labrador

\section{References}

Blaustein, Richard. 1993. "Rethinking Folk Revivalism: Grass-Roots Preservationism and Folk Romanticism.” In Neil V. Rosenberg, ed., 
Transforming Tradition: Folk Music Revivals Examined: 258-274. Urbana: University of Illinois Press.

Lhamon, W.T. 2003. Jump Jim Crow. Lost Plays, Lyrics, and Street Prose of the First Atlantic Popular Culture. Cambridge: Harvard University Press.

Marcus, Greil. 1997. The Old, Weird America: The World of Bob Dylan's Basement Tapes. New York: Picador USA.

Rosenberg, Neil V. 1993. "Introduction." In Neil V. Rosenberg, ed., Transforming Tradition: Folk Music Revivals Examined: 1-25. Urbana: University of Illinois Press.

Mitsui, Toru. "The Reception of the Music of American Southern Whites in Japan." In Neil V. Rosenberg, ed., Transforming Tradition: Folk Music Revivals Examined: 275-293. Urbana: University of Illinois Press..

Seeger, Pete. 1968. "Why Folk Music?" David A. DeTurk and A. Poulin Jr, eds., The American Folk Scene. Dimensions of the Folksong Revival: 44-49. New York: Dell. 